\title{
Acute Toxicity of Tuber Peels of Tacca leontopetaliodes on the Biochemistry and Histol- ogy of Gills and Liver of Clarias gariepinus Juveniles
}

\author{
Bala S. Audu ${ }^{*}$, Jamiu O. Omirinde ${ }^{2}$, Audu I. Wakawa ${ }^{3}$, Ibrahim A. Dalhatu ${ }^{1}$, \\ Jacinta B. Sale ${ }^{1}$ \\ ${ }^{1}$ Department of Zoology, Faculty of Natural Sciences, University of Jos, Nigeria \\ ${ }^{2}$ Department of Anatomy, Faculty of Veterinary Medicine, University of Jos, Nigeria \\ ${ }^{3}$ Department of Biology, Umar Suleiman College of Education, Gashua, Yobe State
}

\footnotetext{
*Correspondence should be addressed to Audu B. Sambo: audusambo@yahoo.com

Received 18th October 2020; Revised 3rd November 2020; Accepted 4th November 2020

(C) 2020 Audu et al. Licensee Pan African Journal of Life Sciences. This is an Open Access article distributed under the terms of the Creative commons Attribution License (https://creativecommons. org/licenses/BY/4.0), which permits unrestricted use, distribution, and reproduction in any medium, provided the original work is properly cited.
}

\begin{abstract}
Background: Increased rate of water pollution has detrimental effects on the health of fish and other aquatic organisms. This invariably affects humans by causing food insecurity, hunger and poverty. In an effort to curb this menace, this study investigated the effects of crude tuber peel extract of Tacca leontopetaliodes on the biochemical and histological parameters of Clarias gariepinus.

Methods: Acute toxicity $\left(96 \mathrm{hr} . \mathrm{LC}_{50}\right)$ test was conducted after a range finding test from which definitive test concentrations of $5.00,4.00,3.00,2.00$, and $1.00 \mathrm{~g} / \mathrm{L}$ were obtained with $0.00 \mathrm{~g} / \mathrm{L}$ as control. One hundred and twenty (120) mixed sex C. gariepinus fingerlings (mean weight, $12.5 \mathrm{~g} \pm 0.5$; length, $13.2 \mathrm{~cm} \pm 0.5)$ were administered definitive concentrations of crude tuber peel extract in duplicate replication. Water quality parameters ( $\mathrm{pH}$, dissolved oxygen, free carbon dioxide, alkalinity), tissue enzymes (Alkaline phosphatase (ALP), Alanine Aminotransferase (ALT), Aspartate Aminotransferase (AST) and histopathological assessments were analysed using standard procedures.

Results: Physico-chemical parameters ( $\mathrm{pH}$, dissolved oxygen, free carbon dioxide and alkalinity) of test tanks containing graded concentrations of $T$. leontopetaliodes were significantly altered $(\mathrm{p}<0.05)$ compared to the control tank. Similarly, the profile of hepatic enzymes (ALP, AST and ALT) displayed marked progressive dose-dependent increase levels relative to the control. Histopathological examination revealed graded deterioration of gills and liver architecture with increase in the strength of the extract $T$. leontopetaliodes

Conclusion: The crude tuber peel extract of T. leontopetaliodes is toxic to fish, thus, washing, processing and discard of $T$. leontopetaliodes in and around riparian systems should be discouraged.
\end{abstract}

Keywords: Acute toxicity, Polynesian arrowroot, organs, enzymes and tissue pathology, African catfish 


\subsection{INTRODUCTION}

Water pollution is the contamination of water bodies such as lakes, rivers, oceans and groundwater by anthropological activities either directly or indirectly [1]. Agrawal et al., [1] further stated that all forms of water pollution affect organisms that inhabit such water bodies by damaging not only the individual species and populations but also the natural biological communities. These deleterious effects occur when pollutants are discharged directly or indirectly into water bodies without adequate treatment to remove harmful constituents. Water pollutants (plant extracts, heavy metals, and industrial effluents) have two poisoning mechanisms on fish, one occurring at high concentrations and provoking a rapid suffocation by destruction of the gill epithelium and the other prevailing at low concentrations which inhibits the main metabolic pathways such as gills, kidney and liver [2].

Tacca leontopetaliodes commonly known as Polynesian arrowroot [3] is a species of flowering plants of the family Dioscoreaceae [4]. It is naturally distributed across West Africa, Southeast Asia and northern Australia. In Nigeria, the plant is mainly found in the middle belt [5] and in the south western States [3]. T. leontopetaliodes has been reported as an important food and medicine to Polynesians and Hawaiians [4]. Polynesians, according to Ukpabi et al., [4] apply the starchy content of the plant to wound to stop bleeding and also treat dysentery when mixed with red clay. The authors further reported that Hawaiians eat the raw tubers to treat stomach ailments such as diarrhoea and stop internal haemorrhage in the stomach and colon. Ukpabi et al., [4] further reported that the starchy part of the tuber is used to feed infants. Similarly, Wardah et al., [6] reported that $T$. leontopetaliodes was utilized to overcome conditions of famine in South Garut, Indonesia.

Toxicity of $T$. leontopetaliodes in mammals has been widely reported [7, 8, 9]. Agbonna et al., [3] also reported $T$. leontopetaliodes to contain anti-nutrients which could be toxic to humans. Similarly, Liu et al., [9] reported tuber peels of $T$. leontopetaliodes as highly toxic to other animals. Available literature has shown that there is paucity of data on toxicity effects of the crude tuber peel extract (CTPE) of $T$. leontopetaliodes on fish. This study was therefore aimed at investigating the acute toxicity effects of CTPE of $T$. leontopetaliodes on biochemistry and histology of gills (the first organ to come in contact with contaminants) and liver (organ responsible for detoxification, biotransformation and excretion of xenobiotics) of Clarias gariepinus in a static non-renewable bioassay. C. gariepinus was chosen for this study because of its abundance in freshwater system and resilience to aquatic pollution.

\subsection{METHODOLOGY}

\subsection{Experimental Fish (Clarias gariepinus)}

A total of 120 mixed sex juveniles of C. gariepinus (mean weight and length: $12.5 \pm 0.5 \mathrm{~g}$ and $13.2 \pm 0.5 \mathrm{~cm}$ ) were purchased from Catfish Experts Global Ventures Farm, Zarmaganda, Jos, Plateau State, Nigeria. The juveniles were acclimatized to laboratory condition for 7 days. Prior to the commencement of the experiment, fish were fed with a commercial feed (Multi feeds ${ }^{\circledR} ; 2 \mathrm{~mm}$ ) at $3 \%$ body weight twice daily. After acclimatization, experimental fishes were transferred into twelve (12) circular plastic tanks with ten (10) fish per tank and fed twice daily (0800 and $1800 \mathrm{hrs).} \mathrm{Photoperiod} \mathrm{was} \mathrm{natural}$ (12 light: 12 dark) and water from all the tanks were changed daily with fresh dechlorinated municipal water.

\subsection{Experimental Plant (T. leontopetaliodes)}

The plant material was obtained from Bakin Ciyawa of Quaapan Local Government Area of Plateau State, Nigeria. The plant floral and tuber parts were taken to the Herbarium section of Plant Science and Technology Department, Faculty of Natural Sciences, University of Jos, Nigeria where it was positively identified as $T$. leontopetaliodes (L.) Kuntze, with voucher number: JUHN20000322. The plant tubers were peeled with a sterilized knife, air-dried for 7 days to a constant weight. The dried peel was pounded with ceramic mortar and pestle into powder and sieved using a $0.2 \mathrm{~mm}$ mesh size sieve to obtain fine particles desired to enhance dissolution water.

\subsection{Determination of Water Quality Parameters}

Water quality parameters such as temperature, hydrogen ion concentration $(\mathrm{pH})$, free carbon (iv) oxide $\left(\mathrm{CO}_{2}\right)$, total alkalinity (TA), and dissolved oxygen (DO) were monitored according to the conventional method of American Public Health Association (APHA) [10]. 
Temperature was measured every day while other parameters were monitored at the beginning and end of the bioassay.

\subsection{Experimental Design}

The $96 \mathrm{hr}$. acute toxicity experimental protocol involved a static non-renewable bioassay as earlier described by Ogueji and Auta [11]. Six (6) rectangular plastic tanks $(45 \times 30 \times 25 \mathrm{~cm})$ containing sixty (60) mixed sex $C$. gariepinus juveniles (mean weight and length: $12.5 \pm 0.5 \mathrm{~g}$ and $13.2 \pm 0.5 \mathrm{~cm}$ respectively) with each tank housing 10 fish were filled with $10 \mathrm{~L}$ of dechlorinated municipal tap water per tank. Five (5) of the tanks were inoculated with various concentrations $(5.00,4.00,3.00,2.00,1.00 \mathrm{~g} / \mathrm{L})$ of crude tuber peel extract (CTPE) of T. leontopetaliodes while the sixth while the sixth tank, the control, was not inoculated but stocked with ten (10) mixed sex juveniles of C. gariepinus [12]. The setup was arranged in a randomized block design [13]. Fish were maintained in a natural light regime (12 light:12 dark) and were not fed throughout the $96 \mathrm{hr}$ bioassay. The setup was replicated.

\subsection{Preparation of Gills and Liver of $C$. gariepinus juveniles for Biochemical Analyses}

Gills and liver were collected and rinsed in distilled water to remove traces of blood [15]. The organs were macerated in normal saline, crushed with laboratory pestle and mortar [15] then centrifuged for 5 minutes at $1000 \mathrm{rpm}$ [16] and the obtained supernatants were transferred into non-heparinised tubes before storage in a refrigerator $\left(0{ }^{\circ} \mathrm{C}\right)$ for biochemical analysis

\subsection{Biochemical Analysis}

The activities of various enzymes; alkaline phosphatase (ALP), alanine aminotransferase (ALT), and aspartate aminotransferase (AST) in the liver and gills of $C$. gariepinus juveniles were determined using colorimetric procedure earlier described by Reitman and Frankel [14].

\subsection{Preparation of Gills and Liver C. Gariepinus juveniles for Histopathological Examinations}

The routine paraffin wax method and haematoxylin-eosin staining techniques during tissue processing previously described by Drury and Wallington [17] and Avwioro [18] were adopted for the processing and examination of the gills and liver tissues of $C$. gariepnus juveniles exposed to T. leontopetaliodes

\subsection{Data Analysis}

Data were analysed using one-way analysis of variance (ANOVA) single classification. Treatment means were separated using Tukey's multiple comparisons test. Level of significance was determined at $\mathrm{P}=0.05$ level of probability

\subsection{RESULTS}

3.1 Water Quality Parameters of Tanks with $C$. gariepinus Juveniles Exposed to Acute Concentration of CTPE T. leontopetaloides

The results of the water quality parameters of experimental tanks are summarized in Table 1. The $\mathrm{pH}$ and dissolve oxygen (DO) values in tanks laden with concentrated grades of CTPE significantly decreased $(p<0.05)$ with the increasing concentration of the extract. On the other hand, the total alkalinity (TA) levels increased significantly $(\mathrm{p}<0.05)$ with the rising concentrations of CTPE. There was no marked difference in the free carbodoxide $\left(\mathrm{FCO}_{2}\right)$ levels in treated tanks except for significant elevated levels in tanks containing 2 and $3 \mathrm{~g} / \mathrm{L}$ of the CTPE. With respect to temperature, there was no significant difference $(\mathrm{p}=0.59)$ in the temperature

Table 1. Water quality parameters of experimental tanks during acute bioassays of $C$. gariepinus juveniles exposed to CTPE of T. leontopetaloides

\begin{tabular}{lllllll}
\hline \multirow{2}{*}{ Parameter } & \multicolumn{5}{c}{ Concentration (g/L) } \\
\cline { 2 - 6 } & 0.00 & 1.00 & 2.00 & 3.00 & 4.00 & 5.00 \\
$\mathrm{pH}$ & $6.93 \pm 0.04$ & $6.25 \pm 0.35$ & $6.43 \pm 0.04$ & $6.38 \pm 0.11$ & $6.23 \pm 0.04$ & $5.83 \pm 0.04^{*}$ \\
Free $\mathrm{CO}_{2}(\mathrm{mg} / \mathrm{L})$ & $2.63 \pm 0.04$ & $2.43 \pm 0.04$ & $3.63 \pm 0.04^{*}$ & $4.53 \pm 0.04^{*}$ & $2.93 \pm 0.04$ & $2.03 \pm 0.04$ \\
TA $(\mathrm{mg} / \mathrm{L})$ & $39.50 \pm 0.71$ & $29.55 \pm 0.64$ & $94.00 \pm 1.41^{*}$ & $107.50 \pm 0.71^{*}$ & $125.50 \pm 0.71^{*}$ & $137.00 \pm 1.41^{*}$ \\
DO $(\mathrm{mg} / \mathrm{L})$ & $3.53 \pm 0.04$ & $3.33 \pm 0.04$ & $3.25 \pm 0.35$ & $3.42 \pm 0.04$ & $2.93 \pm 0.04^{*}$ & $1.93 \pm 0.04^{*}$ \\
Temp $\left({ }^{\circ} \mathrm{C}\right)$ & $24.75 \pm 0.35$ & $25.55 \pm 0.64$ & $25.60 \pm 0.57$ & $25.60 \pm 0.57$ & $25.60 \pm 0.57$ & $25.60 \pm 0.57$ \\
\hline
\end{tabular}

Values with Asterisks $\left(^{*}\right)$ in the row are significantly different compared with the control 
of all the tanks laden with concentrated grades of CTPE compared with the control.

\subsection{Effect of Acute Toxicity of CTPE of T. leontopet-} aloides on Biochemistry of Gills of $C$. gariepinus Juveniles

The mean values of ALP, AST and ALT of gills of $C$. gariepinus juveniles exposed to T. leontopetaloides are presented in Figure 1. Biochemical activities in the gills increased with increase in concentration of the plant extract. The highest mean ALP activity $(6587.63 \pm 1.94 \mathrm{U} / \mathrm{L})$ was recorded in $4.00 \mathrm{~g} / \mathrm{L}$ concentration of $T$. leontopetaloides while the lowest value $(5957.88 \pm 1.94 \mathrm{U} / \mathrm{L})$ was recorded in the control. AST recorded the highest activity $(1903.23 \pm 1.25 \mathrm{U} / \mathrm{L})$ in treatment concentration $5.00 \mathrm{~g} / \mathrm{L}$ and progressively decreased to the lowest value $(1799.83 \pm 2.50 \mathrm{U} / \mathrm{L})$ in concentration $2.00 \mathrm{~g} / \mathrm{L}$. Similarly, the highest ALT activity $(2011.99 \pm 2.50 \mathrm{U} / \mathrm{L})$ was recorded in the highest treatment concentration $(5.00 \mathrm{~g} / \mathrm{L})$ while the lowest value $(1974.86 \pm 2.50 \mathrm{U} / \mathrm{L})$ was recorded in treatment concentration $1.00 \mathrm{~g} / \mathrm{L}$ ). There was no significant differences $(\mathrm{p}>0.05)$ in the activities of ALP, AST and ALT compared to the control.

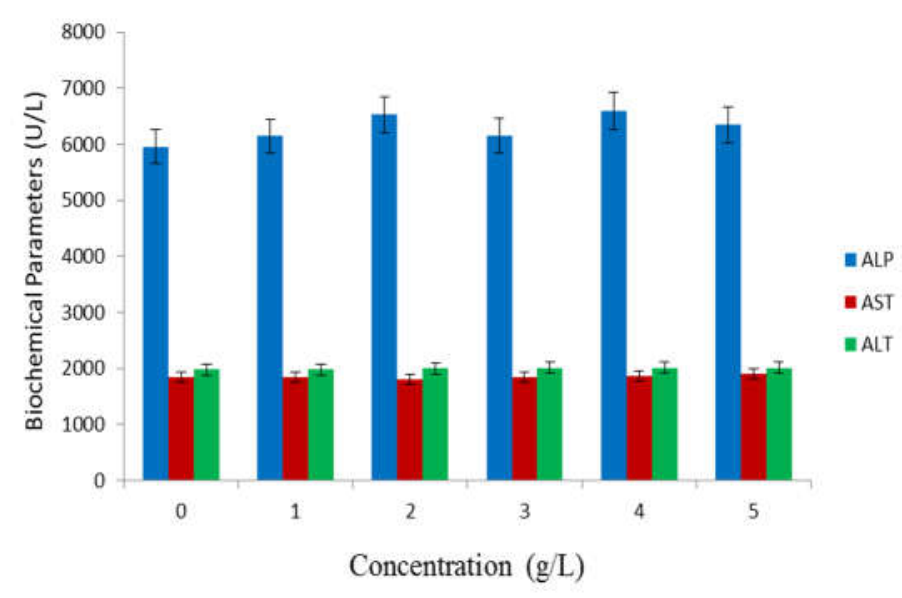

Figure 1. Effect of Crude Tuber Peel Extract of T. leontopetaloides on Gills Biochemistry of C. gariepinus Juveniles

3.3 Effect of Acute Concentrations of CTPE of T. leontopetaloides on Liver Biochemistry of C. gariepinus Juveniles

The effect of CTPE of T. leontopetaloides on liver biochemistry of $C$. gariepinus juveniles is shown in Figure 2. The liver ALP values were significantly reduced $(\mathrm{p}<0.05)$ in C. gariepinus exposed to 3 and $4 \mathrm{~g} / \mathrm{L}$ of CTPE of $T$. leontopetaloides compared to other groups. There was no significant difference $(\mathrm{p}>0.05)$ in the liver ALP values of the control and cat fish treated with $1 \mathrm{~g} / \mathrm{L}$ of the extract.
The trend of ALP values appeared to decrease with increasing concentrations of CTPE of T. leontopetaloides. There was no significant difference $(\mathrm{p}>0.05)$ in the levels of liver AST across the entire exposed groups compared to the control. With respect to ALT levels, there were significant reductions in the hepatic ALT levels in the cat fish exposed to different grades of CTPE of T. leontopetaloides compared to the control. However, there was no significant difference $(p>0.05)$ in ALT levels in the liver of $C$. gariepinus treated with the $1 \mathrm{~g} / \mathrm{L}$ of the extract and the control.

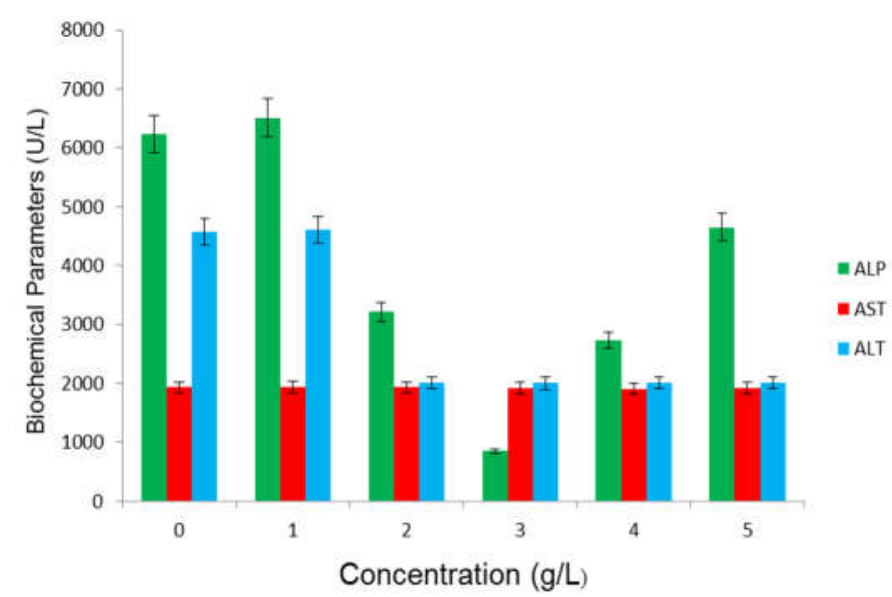

Figure 2. Effect of Crude Tuber Peel Extract of $T$. leontopetaloides on Liver Biochemistry of $C$. gariepinus Juveniles

\subsection{Histopathology of Gills of C. gariepinus Juveniles Exposed to CTPE of T. leontopetaloides}

The histopathological outcomes of gills of the test fish exposed to CTPE of $T$. leontopetaliodes are presented in Plate 1 . There were progressive concentration-dependent increases in histopathological alterations in the gills exposed to various concentrations of $T$. leontopetaliodes. The control showed normal gill histo-architecture characterized by patent interlamella space (star), normal primary (arrowhead) and secondary (black arrow) lamellae. Fish exposed to 1.00 and $2.00 \mathrm{~g} / \mathrm{L}$ of the plant extract showed moderate lamella cell depletion (red arrow) with intact interlamella space (star). There was mild focal lamella cell depletion (red arrow) in gills exposed to 3.00 $\mathrm{g} / \mathrm{L}$ of the plant extract. Extract concentration $(4.00 \mathrm{~g} / \mathrm{L})$ was characterized by severe lamellar cell depletion (red arrow), matted water channels (circle outline) and apical lamella clubbing (black arrow) while the highest extract concentration $(5.00 \mathrm{~g} / \mathrm{L})$ was typified by severe lamella cell depletion and complete histo-architectural distortion (circle outline). 


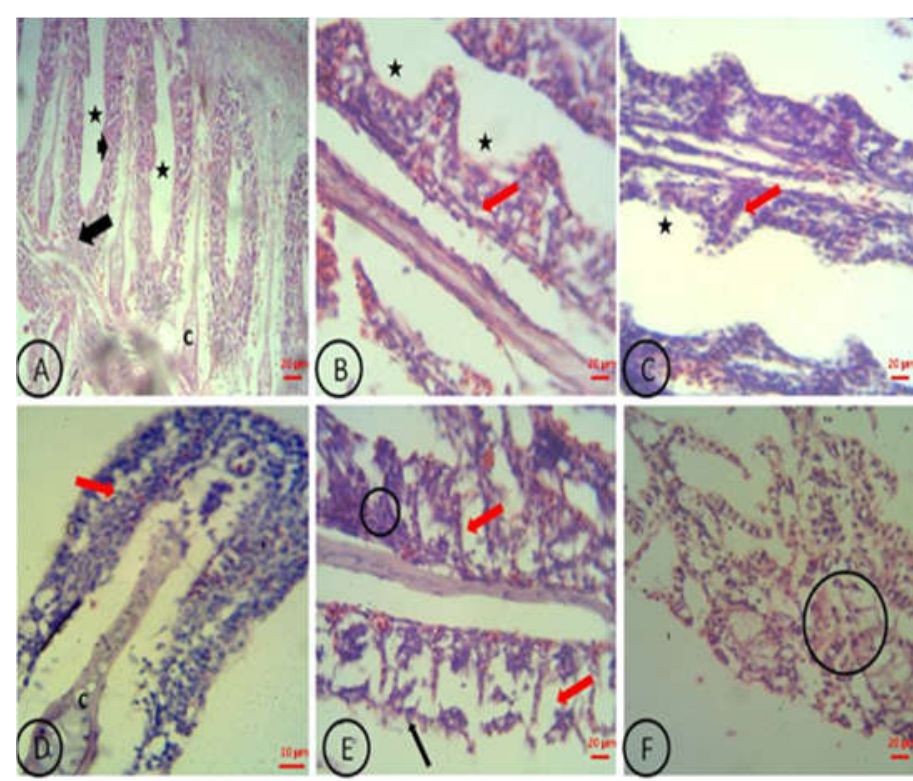

Plate 1: Light micrographs of the gill of Clarias gariepinus exposed to acute concentrations of Tacca leonpetaliodes

A. 0 g/L (Control): Normal gill histo-architecture characterized by patent interlamellar space (star), presence of normal primary (arrowhead) and secondary (black arrow) lamellae and intact ceratobranchial bone (c) B. 1 g/L, C. 2 g/L: Mild lamellar cell depletion (red arrow) with intact interlamellar space (star) D. 3 g/L: Moderate focal lamellar cell depletion (red arrow) E. 4 g/L: Severe lamellar cell depletion (red arrow), matted water channels (circle outline) and apical lamellar clubbing (black arrow) F. 5 g/L: Severe lamellar cell depletion and complete histo-architeural distortion (circle outline). Stain: $\mathbf{H E}$

\subsection{Histopathology of Liver of $C$. gariepinus Juveniles Exposed to CTPE of T. leontopetaloides}

The photomicrographs of Liver of $C$. gariepinus juveniles exposed to CTPE of $T$. leontopetaliodes are shown in Plate 2. The liver in the control showed normal hepatic histoarchiture typified by hepatocytes with regular cellular outline, intact cytoplasm and roundish nucleus (arrow). Liver of the juveniles exposed to concentrations of the plant extract also indicated progressive concentration-dependent increase in histopathological alterations. No visible lesions were observed in the liver of $C$. gariepinus juveniles exposed to lower concentrations (1.00 and $2.00 \mathrm{~g} / \mathrm{L}$ ) CTPE of T. leontopetaliodes whereas concentration the liver exposed to $3.00 \mathrm{~g} / \mathrm{L}$ of the plant extract showed mild hepatocyte degeneration (circle outline). There was severe sinusoidal congestion (arrow) in $4.00 \mathrm{~g} / \mathrm{L}$ concentration while the highest concentration $(5.00 \mathrm{~g} / \mathrm{L})$ was characterized by severe cellular infiltration (arrows) and marked hepatocellular degeneration (circle outline).

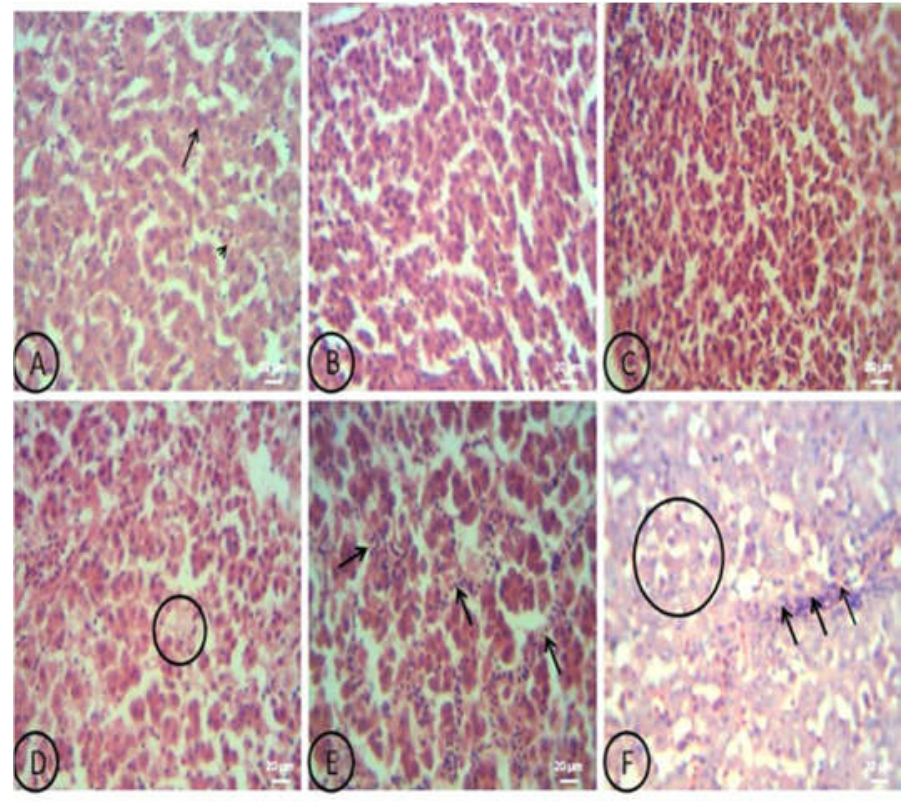

Plate 2: Light micrographs of the liver of C. gariepinus exposed to acute concentrations of $T$. leontopetaliodes.

A. 0 g/L (Control): Normal hepatic histo-architecture typified by hepatocytes with regular cellular outline, intact cytoplasm and roundish nucleus (arrow) B. 1 g/L, C. 2 g/L: No visible lesion D. 3 g/L: Mild hepatocyte degeneration (circle outline) E. $\mathbf{4}$ g/L: Severe sinusoidal congestion (arrow) F. 5 g/L: Severe cellular infiltration (arrows) and marked hepatocellular degeneration (circle outline). Stain: HE.

\subsection{DISCUSSION}

In any aquatic toxicology study, water quality parameters are determined due to the important function they play in the healthy existence of fish [19] since the whole life process of aquatic organisms solely depends on the immediate environment [20]. Any alteration in water quality may affect lives of the inhabitants [21] and any addition of toxicant may cause fluctuations in the water quality variables [22]. In the present study the significant decrease in DO in water loaded with high concentrations of T. leontopetaliodes is suggestive of degrading effects of the plant extract on the oxygen molecules [23] since the DO minimum requirement of $C$. gariepinus is $3-4 \mathrm{mg} / \mathrm{L}$ [24]. The increase in $\mathrm{CO}_{2}$ could be due to the higher rate of oxidation of organic materials than the rate of oxygen replenishment [25] leading to respiratory asphyxiation [26]. Also the decrease in DO and increase in $\mathrm{CO}_{2}$ could have serious impacts on biochemical and histopathological alterations in the gills and liver of $C$. gariepinus juveniles exposed to CTPE of T. leontopetaliodes.

These findings on dissolve oxygen and free carbondoxide are similar to the report of Audu et al., [27] on acute concentrations of B. aegyptiaca exposed to Oreochromis ni- 
loticus fingerlings. Water with high TA level is considered productive for fish culture [12]. The test water of the present study could be considered as ideal for fish culture since the TA range between 29.55 and $137.00 \mathrm{mg} / \mathrm{L}$ is within the recommended level of alkalinity for fresh water system of 5-500 mg/L [28, 29].

Evaluation of organ biochemical parameters are used to ascertain destructive effects of toxicants [30] in fish organs. Plasma enzymes are good pointers in determining ideal range of phytotoxin concentrations [31] in stressed organisms. Enzymes such as ALT, ALP, AST and LDH are analysed to determine different stress conditions in fish $[32,33]$. The increase in ALP, AST and ALT in the serum of gills of $C$. gariepinus juveniles exposed to $T$. leontopetaloides in this study is an indication of tissue impairment caused by stress [34].

This result is similar to the findings of Audu et al., [27] after exposing C. gariepinus fingerlings to grades of waste dry cell battery. The irregular pattern of activities of ALP, AST and ALT observed in the liver of $C$. gariepinus juveniles exposed to T. leontopetaloides in this study is dissonant with the findings of Mekkawy et al., [35], Al-Asqah et al., [32] and Audu et al., [27].

Changes in histopathology of organs are used to evaluate the effect of pollutants on fish health [36]. Histopathological alterations in gills in the present study are positively related with the concentrations of $T$. leontopetaliodes extract. This is in line with the findings of Kumar et al., [37] after exposing Heteropneustes fossilis to varied concentrations of Neem extract, Azadirachtin. Gill lesions (lamella cell depletion and complete histo-architectural distortion) observed in the present study corroborate the observations of $[38,39,12]$. Similar lamella depletion has also been reported by Kumar et al., [37]. The liver of the $C$. gariepinus juveniles exposed to concentrations of T. leontopetaliodes extract also indicated progressive concentrationdependent increase in histopathological alterations. This trend has been similarly reported by Adeyemo [40], Jalaludeen et al., [41], Hadi and Alwan [42] and Rajkumar et al., [43]. The grades in the severity of hepatic lesions (hepatocellular degeneration, sinusoidal congestion and cellular infiltration) observed in this study have further validated the hepatic enzymes results earlier stated and could reflect a remarkable derangement in the normal functioning of the liver. These observations on hepatic histopathological lesions are in agreement with similar studies reported by Audu et al., [12, 39].

Conclusively, CTPE of $T$. leontopetaliodes was found to cause negative effects on physicochemical parameters of water as well as on biochemical and histopathological alterations in the gills and liver of $C$. gariepinus juveniles. Therefore, adequate precautionary measures must be taken when discarding the peels to avoid deposition into aquatic ecosystem so as to maintain healthy aquatic life.

\section{Conflict of Interest}

The authors declare that there is no conflict of interest.

\section{Authors Contribution}

BSA conceived and designed the study, performed manuscript writing and revision and contributed to financial obligations; JOO Performed morphometric analysis, contributed to photomicrographic plates analysis and financial obligations; AIW develop and patterned manuscript to conform with journal style and contributed to financial obligations; AID performed data collection, contributed to data analysis tools and actively involved in the bench work; JBS contributed to data collection and data analysis tools and actively involved in the bench work

\section{References}

1. Agrawal A, Pandey RS, Sharma B. Water pollution with special reference to pesticide contamination in India. Journal of Water Resources and Protection. 2010; 2: 432-448. http://doi.org/10.4236/jwarp.2010.25050

2. Mohsen A, Gamal OE, Sherien HHHS. Acute Toxicity of water-born zinc in Nile Tilapia, Oreochromis niloticus (L.) fingerlings. Proceedings of the Ninth International Symposium on Tilapia in Aquaculture Shanghai, China. 2011.

3. Agbonna AI, Adepoju SO, Ogbonna CIC, Yakubu T, Itelima JU, Dajin VY. Root tuber of Tacca leontopetaloides L. (Kunze) for food and nutritional security. Microbiology: Current Research. 2017; 1(1): 7-13. http:// doi.org/10.4066/2591.8036.16-2241

4. Ukpabi UJ, Ukenye E, Olojede AO. Raw - Material potentials of Nigeria wild Polynesian arrowroot (Tacca leonpetaliodes) tubers and starch. Journal of food Technology. 2009; 7(4): 135-138.

5. Manek RV, Kunle OO, Emeje MO, Builders P, Rama RGV, Lopez GP, Kolling WM. Physical, Thermal and Sorption profile of starch obtained from Tacca leonpetaliodes Starch. 2005; 57(2): 55-61. http://doi.org/10.1002/ star.200400341

6. Wardah EN, Sambas R, Ariani D. Starch products of wild 
plants species Jalaware (Tacca leontopetaloides L.) Kuntze as the source of food security in the south coastal West Java. International Conference on Food Science and Engineering. 2016; 193: 1-10 doi:10.1088/1757$899 X / 193 / 1 / 012035$

7. Tripathi RD, Tiwari KP. Phytochemical investigations of the root of Tacca aspera. Planta Medica. 1981; 41(4): 414-514.

8. Tingley TL, Randall-Hlubak DDA, Leal RM, Jackson EM, Casac JW, Quads JC. Hemscheidt TK, Mooberry SL. Taccalonolies $\mathrm{E}$ and A. Plant-derived steroids with micotybule stabilizing activity. 2003; Cancer Resources. 63: 32113220 .

9. Liu HY, Ni W, Xie BB, Zhou LY, Hao XJ, Wang X, Chen CX. Five new withanolides from Tacca plantaginea. Chemical and Pharmaceutical Bulletin. 2006; 54(7): 992995. http://doi.org/10.1002/chin.200652194

10. APHA. Standard methods for examination of water and wastewater. American Public Health Association. 17th edition, American Public Health Association. Washington D.C., 1989; 1,268pp

11. OECD. Guideline for the Testing of Chemicals: Organization for Economic Cooperation and Development. 2003; 1 $-19 p$.

12. Audu BS, Wakawa IA, Omirinde JO, Garba U, Damshit M.. Histopathological alterations in organs of Nile Tilapia fingerlings exposed to sublethal concentrations of aqueous crude leaves extract of Desert Date. Pan Afr. J. L. S. 2020a; 4(2): 59-67. www.pajols.org

13. Rezende FP, Pascoal LM, Vianna RA, Lanna EAT. Sedation of Nile tilapia with essential oils: tea tree, clove, eucleptus, and mint oils. Review of Caatinga. 2017;30(2): 479-486. https://doi.org/10.1590/1983-21252017v30n223 rc

14. Reitman S, Frankel S. A colorimetric method for the determination of serum of glutamic oxaloacetic and glutamic pyruvic transaminase. American Journal of Clinical Pathology. 1957; 28: 56-63. https://doi.org/10.1093ajc $\mathrm{p} / 28.1 .56$

15. Devi M, Reddy PS, Fingerman M. Effects of exposure on Lactate dehydrogenase activity in the hepatopancreas and abdominal muscle of the fiddler crab, Uca pugilato, Comparative Pharmacology and Toxicology. 1993; 106(3): 739 -742. https://doi.org/10.1016/0742-8413(93)90235-D

16. Ogueji EO, Auta J. Investigation of Biochemical effects of acute concentration of Lambda-cyalothrin on African catfish, Clarias gariepinus Teugels. Journal of Fishery. 2007; 2(1): 86-90. https://doi.org/10.jfish.2007.86.90
17. Drury R, Wallington E. Histological Technique. 4th edition, Oxford University Press, USA. 1967; pp. 279-280.

18. Avwioro OG. Staining reactions of microwave processed tissues compared with conventional paraffin wax processed tissues. European Journal of Experimental Biology. 2011; 1(1): 57-62. www.pelagiaresearchlibrary.com

19. Olusegun AA, Adedayo OO. Haematological responses, serum biochemistry and histology of Clarias gariepinus (Burchell, 1822) exposed to sub-lethal concentrations of cold water fresh root bark extracts of Plumbago zeylanica (Leadwort). Journal of Aquatic Research and Development. 2014; 5: 282-288. http://doi.org/10.4172/21559546.1000282

20. Bolorunduro PI, Abdullah AY. Water quality management in fish culture, National Agricultural Extension and Research Liaison Services, Zaria, Extension Bulletin No. 98, 1996.

21. Suely A, Zabed H, Ahmed, ABA, Mohamad J, Nasiruddin M, Sahu JN, Ganesan P. Toxicological and haematological effect of Terminalia arjuna bark extract on a freshwater catfish, Heteropneustes fossilis. Fish Physiology and Biochemistry. 2015; 1: 1-15. http://doi.org/10.1007/s10695015-014-3

22. Srivastava SJ, Singh ND, Srivastava AK, Sinha R. Acute toxicity of malachite green and its effects on certain blood parameters of a catfish, Heteropneustes fossilis. Aquatic Toxicology. 1995; 31: 241-247. http:// doi.org/10.1016/0166-445(94)00061-T

23. Adedeyi DO, Odo KE. Acute toxicity and haematology of Clarias gariepinus exposed to selenium. International Journal of Agriculture. 2017; 7(9): 64-70. http:// doi.org/10.5376/ija.2017.07.0009

24. Anonymous (n.d). Nile Tilapia (Oreochromis niloticus). www.cabi.org

25. Warren CE. Biology and water pollution control NB Sanders and Co. Philadelphia USA. 1971; 16(3):593-593

26. Chuck, K. (2003). Fishing with poisons. The Bulletin of Primitive Technology, 23. www.primitiveways.com

27. Audu BS, Damshit M, Wakawa IA, Ajima MNO, Sulaiman Y, Wade JW. Toxicity effects of waste dry cell battery on the haematology and biochemistry of blood, gills and liver of Clarias gariepinus fingerlings. World Journal of Advanced Research and Review. 2020b. 6(2): 72-82. http://doi.org/10.30574/wjarr

28. Lawson TB. Fundamentals of aquaculture engineering. Chapman and Hall, New York. 1995. 355pp.

29. Devi PA, Padmavathy P, Aanand S, Aruljothy K. Review 
on water quality parameters in freshwater cage fish culture. International Journal of Applied Research. 2017; 3(5): 114 -120 .

30. Ibrahim MB, Sowemimo AA, Sofidiya MO, Badmos KB, Fageyinbo MS, Abdulkareem FB, Odukoya OA. Sub-acute and chronic toxicity profiles of Markhamia tomentosa ethanolic leaf extract in rats. Journal of Ethnopharm. 2016; 193: 68-75. http://doi.org/10.1016/j.jep.2016007.036

31. Wagner E, Arndt R, Hilton B. Physiological stress, haematological and biochemical responses in rainbow trout brood stock anaesthesia with clove oil, tricaine sulfonate. Aquaculture. 2008. 211: 353-366. http://doi.org/10.1016/S00448486(01)00878-X

32. Al-Asqah NA, Abdel-Warith AA, Younis EM, Allam HY. Haematological and biochemical parameters and tissue accumulations of cadmium in Oreochromis niloticus exposed to various concentrations of cadmium chloride. Saudi Journal of Biological Science. 2015; 22(5): 543-550. http://doi.org/10.1016/j.sjbs.2015.01.002

33. Akinrotimi OA, Edun OM, Ukwe OIK. Effects of anaesthetics on metabolic enzyme activities in African catfish, Clarias gariepinus (Burchell, 1822). Journal of Fisheries Science. 2018; 1(1): 7-10. www.fisheriessciences.com

34. James R, Sivakumar V, Sampath K, Rajendran P. Individual and combined effects of zinc; cadmium and copper on growth of Oreochromis mossambicus. Indian Journal of Fisheries. 1991; 38: 198-200.

35. Mekkawy AA, Mahmoud UM, Wassif ET, Naguib M. Effects of cadmium on some haematological and biochemical characteristics of Oreochromis niloticus (Linnaeus, 1758) dietary supplemented with tomato paste and vitamin E. Fish Physiology and Biochemistry. 2011; 37: 71-84. http:// doi.org/10.1007/s10695-010-9418-3

36. Naeemi A, Jamili S, Shabanipour N, Mashinchian A, Shariati FS. Histopathological changes of gill, liver, and kidney in Caspian kutum exposed to linear alkylbenzene.
Iranian Journal of Fisheries Science. (2013). 12(4): 887897.

37. Kumar A, Prosad MR, Srivastava K. Brachial histopathological study of catfish, Heteropneustes fossilis following exposure to purified Neem extract, Azadirachtin. World Journal of Zoology. 2010; 5(4): 239-243.

38. Srivastava SK, Tiwari PR, Ajai KS. Chlorpyrifos- induced Histopathological changes in the gill of freshwater catfish Heteropneustes fossilis. Biological physiology of animals. 1989; 13: 23-28.

39. Audu BS, Omirinde JO, Gosomji IJ, Wazhi PE. Histopathological changes in the gill and liver of Clarias gariepinus exposed to acute concentrations of Vernonia amygdalina. Animal Research International. 2017; 14(1); 25762587. www.zoo-unn.org

40. Adeyemo OK. Haematological and histological effects of cassava mill effluent in C. gariepinus. African Journal of Biomedical Research. 2005; 8(3): 179-183. http:// doi.org/10.4314/ajbr.v813.35747

41. Jalaludeen MD, Arunachalam M, Raja M, Nandagopal S, Showket AB, Sundar S, Palanimuthu D. Histopathology of the gill, liver and kidney tissues of the freshwater fish tilapia mossambica exposed to cadmium sulphate. International Journal of Advanced Biological Research. (2012). 2 (4): 572-578. www.scienceandnature.org

42. Hadi A,. Alwan SF. Histopathological changes in gills, liver and kidney of fresh water fish, Tilapia zillii, exposed to aluminium. International Journal of Pharmacy and Life Sciences. 2012; 3(11): 2071-2051.

43. Rajkumar, KS., Kanipandian, N. and Thirumurugan, R. Toxicity assessment on haemotology, biochemical and histopathological alterations of silver nanoparticlesexposed freshwater fish Labeo rohita. Applied Nanoscience. 2016; 6: 19-29. http://doi.org/10.1007/s13204-0150147-7 